\title{
Amphibia, Anura, Centrolenidae, Vitreorana uranoscopa (Müller, 1924): Distribution extension in the state of Rio Grande do Sul, Brazil
}

\author{
Iberê Farina Machado ${ }^{1 *}$, Leonardo Felipe Bairos Moreira ${ }^{1}$, Roger Borges da Silva ${ }^{2}$, Rafael Gustavo \\ Becker $^{2}$ and Alex Sandro Oliveira Mesquita ${ }^{2}$ \\ 1 Universidade do Vale do Rio dos Sinos - UNISINOS, Laboratório de Ecologia e Conservação de Ecossistemas Aquáticos. Avenida Unisinos, 950. \\ CEP 93022-000. São Leopoldo, RS, Brazil. \\ 2 Biota Soluções Ambientais. Caixa Postal 05. CEP 93800-000, Sapiranga, RS, Brazil. \\ * Corresponding author. E-mail: iberemachado@gmail.com
}

\begin{abstract}
The glass frog Vitreorana uranoscopa (Müller, 1924) has been considered a vulnerable species for the state of Rio Grande do Sul, southern Brazil. This note recorded the presence of the species for São Marcos municipality, extending the species distribution towards eastern region of the state.
\end{abstract}

The genus Vitreorana currently comprises eight species of glass frogs occurring at elevations below 1,900 $\mathrm{m}$ in the Cordillera de la Costa of Venezuela, Guiana Shield, Amazonia of Brazil, Colombia and Ecuador, and in the Atlantic Forest of Brazil and Argentina (Lima et al. 2006; Guayasamin et al. 2009). In Brazil, the genus include the species Vitreorana oyampiensis (Lescure, 1975), Vitreorana eurygnatha (Lutz, 1925), Vitreorana parvula (Boulenger, 1895), and Vitreorana uranoscopa (Müller, 1924) (Lima et al. 2006; Guayasamin et al. 2009).

To date Vitreorana uranoscopa is known from southeastern and southern Brazil (Eterovick et al. 2005; Garcia and Vinciprova 1998), and northeastern Missiones, Argentina (Stetson 2001). In the state of Rio Grande do Sul, specimens of $V$. uranoscopa were recorded only in municipality of Barracão (Garcia and Vinciprova 1998). Herein, we present a new location for $V$. uranoscopa, broadening its distribution in the state of Rio Grande do Sul (Figure 1).

During bimonthly field expeditions between November 2008 and November 2009, we found specimens of $V$. uranoscopa (Figure 2A and B) in the barrage of Environmental Protection Area of the Pequena Central Hidrelétrica São Marcos along a small stream tributary of

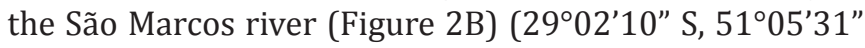
W; $532 \mathrm{~m}$ above sea level). Individuals were found over the year with vocalization activity in August until December, and ovoposition in November 2009 (Figure 2C and D). Maximum abundance was recorded in December, when six males and two females were found. The local flora belongs to the region phytoecological Araucaria forest (Teixeira et al. 1986) on the deciduous forest ecosystems that are considered to be associated with the Atlantic Forest (Brasil 2006).

Voucher specimens are deposited at the Museu de Ciências e Tecnologia da Pontifícia Universidade Católica do Rio Grande do Sul (MCP 9986 and MCP 9987) (License IBAMA - 207/2008). The present record extends species range $c a .154 \mathrm{~km}$, towards eastern region of the state of Rio Grande do Sul, in a straight line from the previous report at São Marcos municipality (Figure 2). In the state of Rio Grande do Sul, V. uranoscopa has been considered a rare species, showing small populations with restrict distribution in preserved fragments of riparian forest (Garcia and Vinciprova 2003). For this reason, the species has been classified as vulnerable in the red list of threatened species from the state of Rio Grande do Sul (Fontana et al. 2003). This report presents a small population that occupies a protected area in the southern distribution of the genus in Brazil.

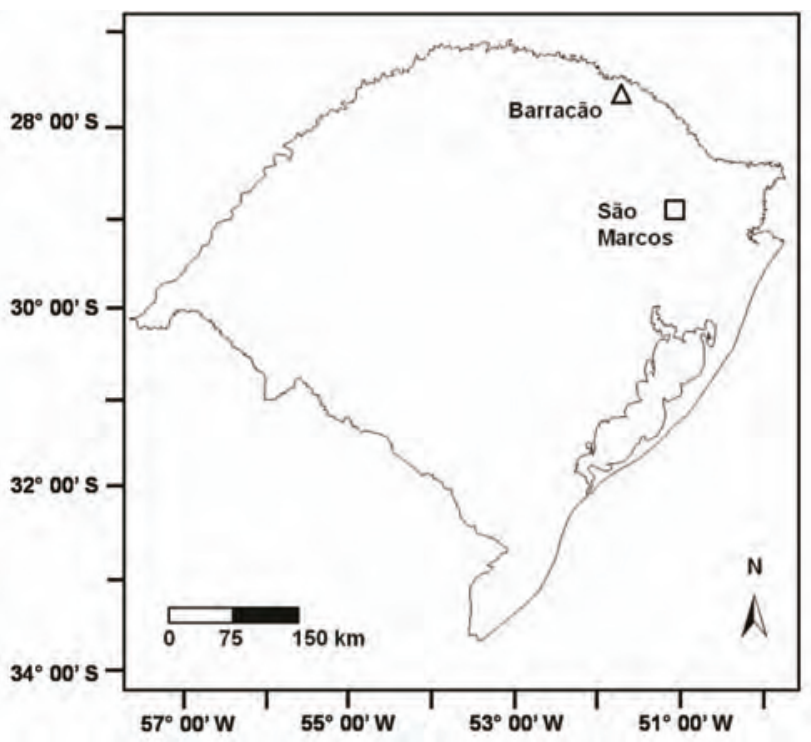

Figure 1. Map of the state of Rio Grande do Sul showing the Área de Proteção Permanente da Pequena Central Hidrelétrica de São Marcos (square) and the municipality of Barracão (triangle). 

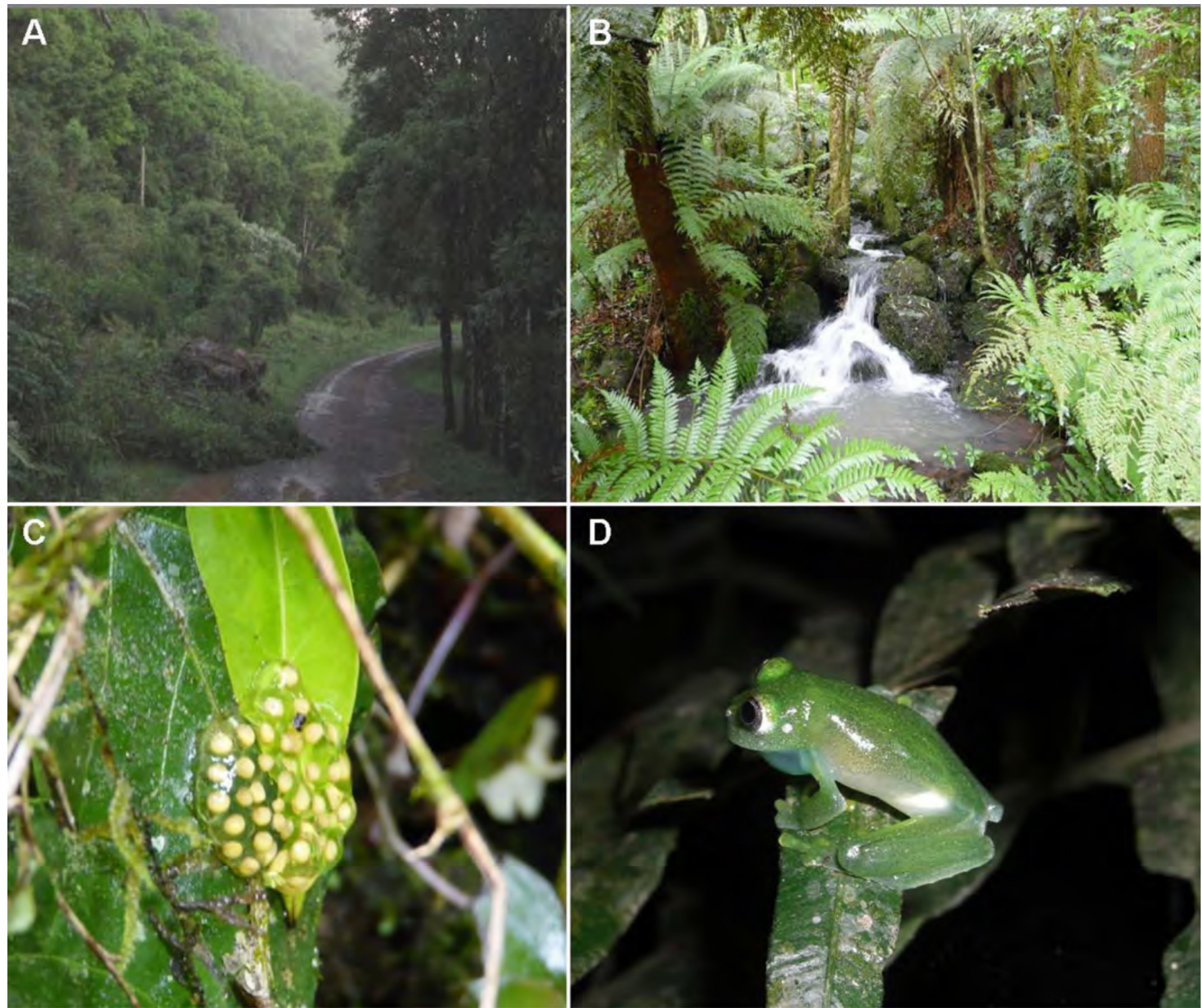

FiguRE 2. (A) General vegetation of the area, (B) Small stream habitat (C) Ovoposition on leaves and, (D) Male of Vitreorana uranoscopa from Área de Proteção Permanente da Pequena Central Hidrelétrica de São Marcos, Rio Grande do Sul, Brazil. Photos by Iberê F. Machado.

ACKNOWLEDGMENTS: This research was supported by funds from Hidrelétrica Rio São Marcos. We thank IBAMA for license permit and to Ana Rolon and Marina S. Dalzochio by help in editing the map and figures. This manuscript was improved by the comments of anonymous reviewer and by Daniel Loebmann.

\section{Literature Cited}

Brasil. Lei ${ }^{\circ} 11.428$, de 22 de dezembro de 2006. Dispõe sobre a utilização da vegetação nativa do Bioma Mata Atlântica, e dá outras providências. Diário Oficial da União, de 26 de dezembro de 2006.

Eterovick, P.C., A.C.O.Q Carnaval, D.M. Borges-Nojosa, D.L. Silvano, M.V. Segalla and I. Sazima. 2005. Amphibian declines in Brazil: an overview. Biotropica: 166-179.

Fontana, C.S., G.A. Bencke and R.E. Reis. 2003. Livro vermelho da fauna ameaçada de extinção no Rio Grande do Sul. Porto Alegre: Edipucrs. $632 \mathrm{p}$.

Garcia, P.C.A. and G. Vinciprova. 1998. Range extension of some anuran species for Santa Catarina and Rio Grande de Sul States, Brazil. Herpetological Review: 117-118.

Garcia, P.C.A. and G. Vinciprova. 2003. Anfíbios; p. 154-155 In C.S. Fontana, G.A. Bencke and R.E. Reis (ed.). Livro vermelho da fauna ameaçada de extinção no Rio Grande do Sul. Porto Alegre: EDIPUCRS.

Guayasamin, J.M., S. Castroviejo-Fisher, L. Trueb, J. Ayarzagüena, M. Rada, and C. Vilà. 2009. Phylogenetic systematics of glassfrogs (Amphibia: Centrolenidae) and their sister taxon Allophryne ruthveni. Zootaxa 2100: 1-97.
Lima, A.P., W.E. Magnusson, M. Menin, L.K. Erdtmann, D.J. Rodrigues, C. Keller and W. Hödl. 2006. Guia de sapos da Reserva Adolpho Ducke, Amazônia Central $=$ Guide to the frogs to Reserva Adolpho Ducke, central Amazonia. Manaus: Áttema Design Editorial. 168 p.

Stetson, R.E. 2001. Distribucion geografica de Hyalinobatrachium uranoscopum (Ruiz Carranza \& Lynch, 1993) (Anura: Centrolenidae). Geographical distribution of Hyalinobatrachium uranoscopum (Ruiz Carranza \& Lynch, 1993) (Anura: Centrolenidae). Cuadernos de Herpetología: 167.

Teixeira, M.B., A.B. Coura-Neto, U. Pastore and A.L.R. Rangel-Filho. 1986. Vegetação. As regiões fitoecológicas, sua natureza e seus recursos econômicos. Estudo fitogeográfico; p.541-632 In IBGE. Levantamento de recursos naturais v. 33. Rio de Janeiro: Instituto Brasileiro de Geografia e Estatística,

RECEIVED: April 2010

REviSED: May 2010

ACCEPTED: July 2010

PUBLISHED ONLINE: August 2010

EDITORIAL RESPONSIBILITY: Daniel Loebmann 